\title{
Chief executive officer compensation sensitivity in the South African mining industry
}

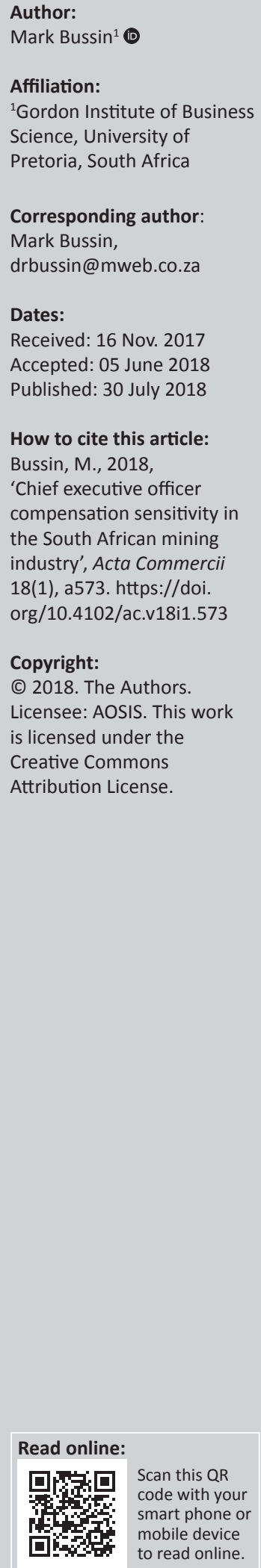

Orientation: The level of chief executive officer (CEO) compensation and its relationship with organisational performance has generated considerable interest worldwide. In light of compromised mining productivity as a result of the recent labour unrest in South Africa, some commentators have questioned the justification of certain CEO compensation in the country's mining industry.

Research purpose: The primary purpose of this study was to describe the relationship between CEO compensation and organisational performance in the South African mining industry.

Motivation for the study: A deeper understanding of the relationship would enhance knowledge when developing optimal CEO reward systems to ensure sustainability of the mining industry within the South African context.

Research design, approach and method: The research was a quantitative, archival study involving 30 mining companies over a 5-year period. The statistical analysis techniques used in the study included analysis of normality variance and multivariate regression.

Main findings: The main finding of the research was that there was a moderate to strong relationship between CEO compensation and organisational performance in the South African mining industry. However, operating expenses have progressively increased, putting performance under pressure. Furthermore, it was also found that organisation size plays an influential role in CEO compensation levels.

Practical/managerial implications: While the CEO compensation appears to be generally aligned with the organisational performance, the findings suggest that boards of directors should focus on structuring reward systems more optimally to mitigate managerial rent seeking in large companies and unsustainability in smaller companies.

Contribution/value-add: This study has contributed to the body of existing knowledge on executive pay for performance in the context of the South African mining industry. In addition, the study has demonstrated that the other measures related to non-performance need to be considered in executive compensation design. The study adds practical value in contributing to information for engagements with stakeholders such as organised labour on executive pay.

\section{Introduction}

The topic of executive compensation has been one that has generated interest and debate for over half a century. There has been a dramatic increase in interest in the relationship between executive compensation and organisational performance over the past two decades (Rau 2017). The advent of increased corporate governance, including greater transparency over the nature and quantum of executive compensation, has led to new regulation worldwide. In the USA, the Securities and Exchange Commission has now adopted rules which require companies to disclose the median pay of the workforce with that of the chief executive officer (CEO) and, similarly, the UK Government's Green Paper on Corporate Governance Reform also suggests pay-ratio disclosure (Deloitte 2017).

In South Africa, the King Committee published the King IV Report on Corporate Governance on 01 November 2016. Remuneration has been given far greater prominence in King IV, and it is clear that it is the Board's responsibility to ensure fair and responsible executive remuneration practices (Deloitte 2017).

Executive compensation is vital in attracting, motivating and retaining the most senior employees of an organisation and its efficiency and effectiveness are measured by sustained organisational 
success at the least economic cost to shareholders (Bussin 2012; Faulkender et al. 2010; Shaw \& Zhang 2010). It is not only the cost of executive compensation that has garnered attention in the literature and the media but also the cost of executive compensation relative to the cost of lower paid employees. The disparity in earnings has become an issue of societal concern worldwide (Deloitte 2017). In South Africa, where income inequality and widespread unemployment are critical issues of national concern, the topic of executive compensation contributes to an already acrimonious and heated debate (Lee 2016).

Various features of the mining industry in South Africa have made it an ideal setting for the expansion of CEO payperformance sensitivity studies. The recent instability in this industry together with the critical role of mining in the South African economy makes comprehensive analysis of the link between CEO pay and performance sensitivity important for successful transformation of the sector (Antin 2013; Molele \& Letsoalo 2012). Furthermore, despite the recent loss of productivity in South African mining owing to deteriorating labour relations characterised by violence and unrest, there are still limited studies on the South African mining industry.

The salaries of mining CEOs have been increasing at an exceedingly high rate, while dividends per share over the same period have decreased significantly (Crowley 2013). The perception of the impact of executive compensation on mining industry performance is further reinforced by recent media publications which blame labour unrest on the widening income inequality gap between mining executives and ordinary workers (Seccombe 2013; Van Vuuren 2013). High income inequality is broadly seen as the catalyst for labour disputes, which usually result in the loss of production time (Bussin 2015; Molele \& Letsoalo 2012; Steyn 2013). This study sought to provide a better understanding of the relationship between executive pay and performance in the South African mining industry by investigating historical relationships between the wages of the most senior managers and organisational performance.

According to a review of the literature, conflict of interest exists between shareholders and management, referred to as the principals and agents, respectively. The literature that addressed these contracting problems that may occur between the principal and agent with competing interest is known as agency theory (Edmans \& Gabaix 2009; Eisenhardt 1989; Jensen 1983; Schneider 2013). This is achieved through optimal contracting theory, which is concerned with appropriately incentivising managers to eliminate managerial rent seeking behaviour. Corporate governance is the main tool used to manage these problems, resulting in additional costs. These costs incurred by shareholders to manage the agency problem are known as agency cost. This theory forms the key component of the foundation for executive pay for performance.

The main purpose of an optimally designed pay for performance contract is to extract concentrated effort from managers to maximise shareholder value and prevent rent extraction. However, various factors were identified as potentially increasing agency problems rather than mitigating them. These include the power that managers have to influence their salary structural design and level, and the concept that the executive compensation is based on the relative ranking system instead of value added by the individual executive (Bussin 2015; Edmans \& Gabaix 2009; O'Reilly \& Main 2010; Shaw \& Zhang 2010). The impact of CEO labour market dynamics is also considered to influence CEO compensation (Bussin 2012). Various measures of CEO compensation and organisational performance are used in the reviewed literature (Bussin 2012; De Wet 2012; Modau 2013). The CEO compensation components were mainly fixed salary, short-term (STI) and long-term incentives (LTI), while the measures of organisational performance were mainly subdivided into market and accounting-based measures of performance (Bussin 2012). In this study, LTIs, which are commonly paid in stocks, were omitted from the investigation.

This empirical study examined the relationship between CEO compensation and organisational performance in the South African mining industry between the years 2009 and 2013. It aims to provide a better understanding of the relationship between executive compensation and organisation performance in the mining industry.

The debate pertaining to executive remuneration in South Africa has been dominated by the widening income inequality between executives and ordinary workers in the South African mining industry, during a challenging time in the sector. This debate was mainly stimulated by media reports on perceived pay for poor performance and the alleged link between exorbitant executive compensation and instability in the sector. Questions have been raised as to whether the level of salary disparity between executives and the lowest paid workers in the mining industry was negatively impacting the organisational performance. This is mainly because the high income inequality is broadly seen as the catalyst for labour disputes, which usually result in the loss of production time (Molele \& Letsoalo 2012; Steyn 2013).

\section{Literature review Executive compensation}

The concept of executive compensation includes all payments made to executive members of the board including the CEO. Desirable compensation packages are created to ensure the ability of the organisation to attract and retain the best possible CEOs. The most common determinants for executive compensation are organisation size; organisation performance; executive-specific factors; organisation structure; job or position-specific factors; and job complexity (Bussin 2012). Executive compensation is essentially a demonstration of how reward and business strategy can be integrated through key performance indicators (KPIs) to ensure that the business attains its objectives (Topazio 2008).

The structure of executive compensation is determined by the compensation committee of the board by combining different 
components of the compensation at the desired magnitude, in an effort to ensure a balanced structure that protects shareholders against opportunistic actions by executives. Shaw and Zhang (2010) state that efficient compensation contracts link executive compensation with organisation performance, thus providing strong incentives for executives to operate in the best interests of the shareholders.

The early thinking with regard to executive compensation was built on the principal-agent theory. This theory asserts that the structure and management of owner-controlled organisations differ significantly from that of management-controlled organisations (Tosi \& Gomez-Mejia 1989). The separation of ownership and control leads to two distinct sets of actors: the principal who is a shareholder in the corporation, and the agent, who acts as a manager for the principal. The relationship between the two actors is inherently characterised by conflict. Managers consistently act in a manner that promotes selfinterest and are said to be 'rent seeking', wishing for greater compensation while working less. The shareholders' goal is for profit maximisation (O'Reilly \& Main 2010).

The principal-agent conflict is further exacerbated by the fact that the CEO will never experience the same risk as shareholders without pledging his or her own capital, and shareholders typically employ agents so that they can focus on running the business from a pragmatic perspective, free of the emotional burden that investor risk creates (O'Reilly \& Main 2010). The need for greater compatibility and alignment has given rise to optimal contracting theory which focuses on aligning managers' and shareholders' interests through the use of financial incentives. Optimal contracts serve the needs of both the principal and the agent by incentivising CEOs to work in the best interests of the organisation while at the same time maximising their own personal gain (Edmans \& Gabaix 2009). If the contract is indeed optimal, it remedies the agency problem but relies on pay-performance sensitivity.

Managerial power theory (Bebchuk \& Fried 2004; Bebchuk, Fried \& Walker 2002) was established by analysing the relationship between executive compensation and organisational performance following the financial crises of the 21st century. It suggests that executive managers have the power to influence the level and components of their compensation (Schneider 2013). This influence over compensation has resulted in organisational inefficiencies owing to unjustifiably high compensation relative to returns, resulting in an aggravated agency problem.

Proponents of managerial power theory suggest that a psychological contract exists between managers and boards that provides incentives that negatively impact the design of efficient contracts. They assert that the influence of the $\mathrm{CEO}$ on the appointment and pay of board members, who in turn are entrusted with the responsibility of overseeing and designing CEO compensation, creates room for the abuse of power (Schneider 2013). This executive influence on corporate resources creates deficiencies in the structural design of executive compensation.

\section{Components of chief executive officer compensation}

The structural design of CEO compensation is seen as an important device to reward or punish CEOs for organisational performance. This is achieved through a variable performancesensitive pay structure or even termination of the contract in the case of poor performance (Bussin \& Nel 2015; Graffin, Boivie \& Carpenter 2013; Frydman \& Saks 2010). South African CEO compensation structure traditionally comprises three main components, namely total guaranteed package, STI pay and LTI pay. These components are illustrated in Figure 1.

For the purpose of this study, only the guaranteed package (fixed pay) and STI component of CEO compensation were used. Bussin and Blair (2015) argue that using the expected STI component of CEO compensation instead of the LTI component provides more accurate results of the relationship between CEO compensation and organisation performance. This is because the CEO may choose to defer cashing out their benefits, which would result in the differed reporting of the transaction on the organisation's financial statement. While this argument is valid, the effect of using STIs is not expected to have significant impact on the overall findings as the results are specific to the products of total CEO compensation. Furthermore, the interpretation of findings takes into account the fact that the relationship between the CEO compensation and shareholder returns is unlikely to be excessively impacted, provided that the specific performance measures are matched with the appropriate compensation component (Nyberg et al. 2010).

\section{Measures of organisational performance}

While it is widely accepted that organisational performance should affect CEO compensation, there is no consistency in the measures of organisational performance that should be selected (Bussin \& Blair 2015; Shaw 2011). Previous studies on the relationship between CEO compensation and organisation performance indicate that results are influenced by the type of industry and performance measures analysed (Bussin \& Blair 2015; Bussin \& Nel 2015). It is suggested that it would be prudent to use shareholder return as a measure of performance because pay for performance aligns the interests of the executives with those of the shareholder in terms of the principal-agent theory (Goergen \& Renneboog 2011; Gregg, Jewell \& Tonks 2012; Murphy 1985; Ozkan 2011). Bussin and Blair (2015) argue that the overriding principle is to ensure that all key performance measures are studied in order to limit the influence on the research results.

The two main measures of organisation performance used in South Africa are accounting-based and market-based measures (Bussin \& Blair 2015). Accounting-based measures comprise financial performance records or ratios used to measure the performance of an organisation. These measures have recently been under the spotlight in South Africa as the 


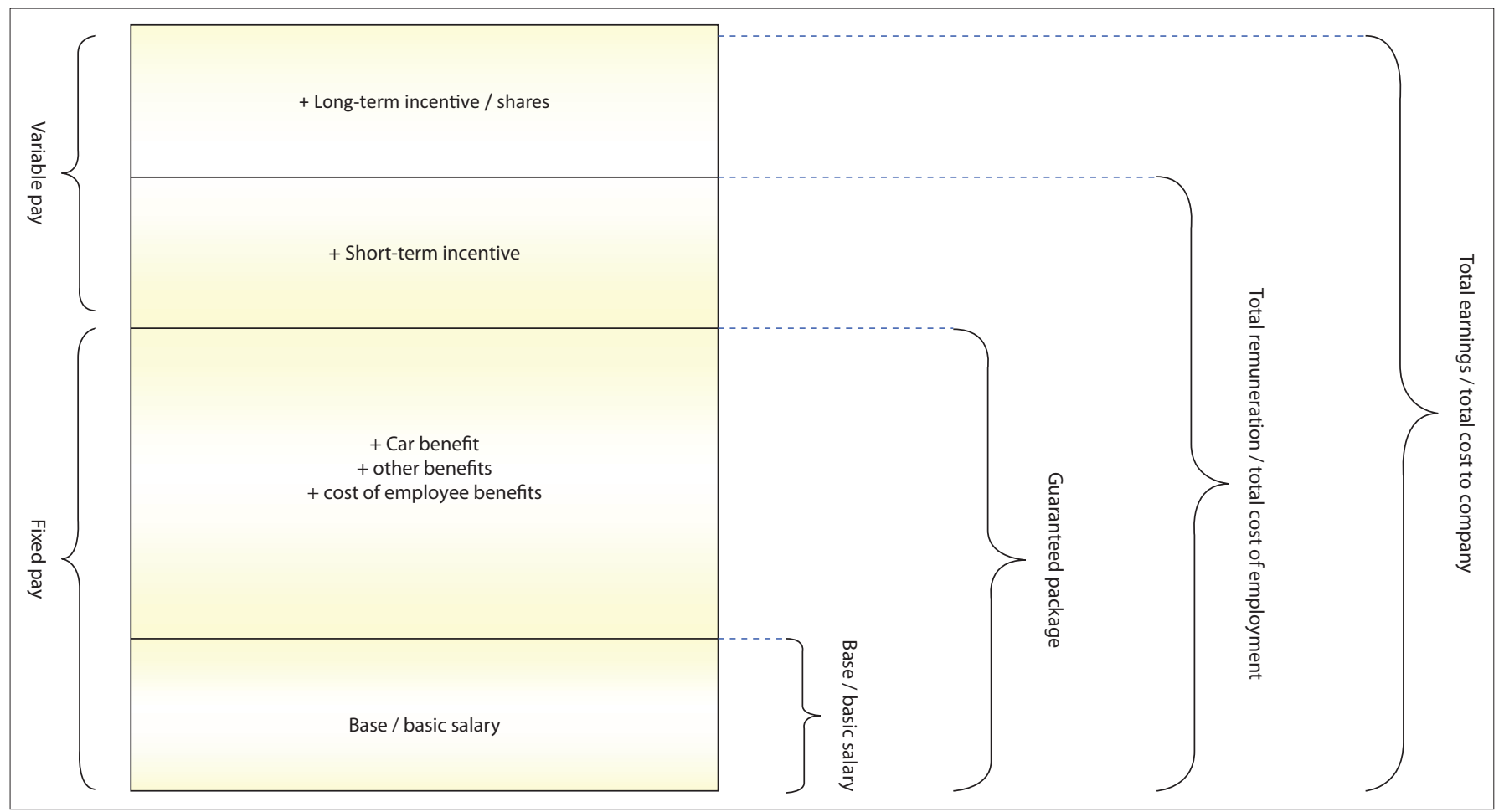

FIGURE 1: Components of chief executive officer compensation in South Africa (Bussin 2012).

Steinhoff Corporate scandal has shown how questionable accounting measures involving off-balance sheet transactions and inflated revenues have led to massive financial losses (Cairns 2017). Market-based performance measures use the equity markets' performance as a measure of how well the organisation is doing. The financial performance of an organisation can be measured by evaluating its financial statements over a period of time. Higgins (2009) argues that the levers of financial performance are the same for all companies. This makes accurate comparison of the financial performance of companies possible.

The Ernst \& Young (2013) survey results for the study 'Remuneration Governance in South Africa' provided an overview of trends in remuneration related issues in South Africa over a period of two consecutive years, and was adopted as a framework to determine the key performance measures to be used for this study.

\section{Chief executive officer compensation in the South African mining industry}

With a Gini coefficient of more than 0.6, South Africa is one of the most unequal societies in the world. Unemployment, income inequality and poverty are matters of great concern in South Africa (Lee 2016; Van der Berg 2014). Goergen and Renneboog (2011) identified South Africa as a country with relatively high CEO compensation. They also illustrated that in the 10-year period between 1997 and 2006, South African CEO compensation (among companies with at least US\$500 million in worldwide annual sales) increased at an above inflation annual rate of $9.8 \%$. However, no link was made between this relatively high rise in the levels of CEO compensation and economic growth or the ordinary worker's salary. The widening income inequality between ordinary workers and management is fuelling the debate on the rationale for seemingly exorbitant executive compensation and its relationship with organisation performance, especially in the South African mining industry.

The mining industry has played a key role in South Africa's post-democracy transformation as one of the main providers of employment to many semiskilled migrant workers from rural South Africa and neighbouring countries. However, the levels of mining executive compensation have recently come under scrutiny. It was reported that pay for CEOs at South African mining companies increased excessively in the decade to 2012, while dividends per share dropped $25 \%$ (Crowley 2013). Furthermore, Carte (2011) states that South African mining and resource executives took home more pay than their telecom and banking counterparts in 2010, while Seccombe (2013) claimed that mining executive pay is out of proportion with their organisational performance and recommended a review of the way compensation packages are structured.

It has also been reported that the chief executives of the top three gold and platinum mines in South Africa earned a collective remuneration totalling ZAR140 million in 2012, leaving workers and unions indifferent to pleas of poverty by mining houses in ongoing wage negotiations (Van Vuuren 2013). The large remuneration of these chief executives highlights the disparity between executive compensation and the earnings of lower level employees, demonstrating the vast inequality that exists. The same article claimed that CEO remuneration at 10 of South Africa's biggest mining groups for the 2012 financial year showed that total compensation tended 
to increase in the opposite direction of most organisations' operational and financial performances, during a difficult period for the country's mining industry. Political and labour analysts have blamed executive compensation for the growing income gap, which has reached levels unseen since the demise of apartheid (Molele \& Letsoalo 2012; Steyn 2013). This has been cited as one of the key reasons for the wave of illegal strike actions in the mining industry. The salaries of chief executives in the mining sector have quadrupled over the past few years despite the global economic crisis and are 150 times higher than the pay of an average mineworker (Van Vuuren 2013).

Cao and Wang (2013) argue that understanding the factors that determine the CEO incentive pay to organisation performance ratio is paramount to understanding the increase in CEO compensation. They state that the two vital factors in compensation to organisation performance ratio are CEO job mobility and organisational risk. The chief executive officer job mobility is as a result of high demand for skilled CEOs, resulting in skills retention when the competition for resources is rife. Organisational risk refers to the structure of the risks the organisation is exposed to within its operating environment. Cao and Wang (2013) assert that pay for performance is dependent on the risk appetite of the agent. The more risk averse they are, the lower the pay for performance and vice versa. This implies that pay for performance could be higher in the South Africa mining industry because of high competition for resources nationally and higher levels of risk relative to other sectors.

The main objective of this research was to examine the relationship between measures of CEO compensation and organisational performance in the South African mining industry. The research aimed to investigate the nature and significance of the relationships between the measures of CEO compensation and the measures of organisational performance.

The hypothesis for the study was:

There was a significant positive relationship between CEO compensation and organisational performance in the South African mining sector over the period 2009-2013.

\section{Research design}

\section{Research approach}

This empirical research adopted an archival, longitudinal approach based on a descriptive quantitative research design. The study involved the analysis of secondary time series data for CEO compensation components and organisational performance measures over the period 2009-2013.

\section{Research method}

\section{Research participants}

The population in this study included all mining companies that were operational and listed on the Johannesburg Stock Exchange (JSE) between the years 2009 and 2013. All JSE listed companies were required to disclose directors' compensation in terms of the King III corporate governance code on executive compensation (IoDSA 2009). The CEO compensation and organisational performance data were acquired from the McGregor BFA database (a provider of business research data including all JSE listed organisations) and archived integrated organisational annual reports.

\section{Sampling}

The initial sample contained all mining organisations listed on the JSE. A purposive sampling technique was adopted by hand-picking JSE listed mining organisations with all the required measurement variables published and archived in the McGregor BFA database. Of the 45 mining organisations that were listed at the time of acquiring the data, 15 organisations were excluded as they had inadequate data on the McGregor BFA database or were not listed on the JSE for the entire study period.

\section{Measuring instruments}

The measurement variables used for CEO compensation and organisational performance included CEO compensation variables:

- the guaranteed total package made up of basic salary and fixed benefits

- the STI component of CEO compensation.

Long-term incentives, which are commonly paid in stocks, were omitted from the study.

Organisational performance variables used were common ones found in the literature to allow for comparability. Accounting measures were the following:

- return on equity (ROE), which is made up of profit margin, total asset turnover and equity multiplier

- earnings before interest, tax, depreciation and amortisation (EBITDA)

- headline earnings per share (HEPS)

- market-based measures

- change in share price

- market capitalisation.

\section{Research procedure and statistical analysis}

Once the relevant data were sourced, they were sorted in accordance with the research design requirements using Microsoft Excel. This was followed by quantitative statistical analysis to examine whether there was a relationship between the variables within the collected data. To achieve this, a multivariate regression analysis of the organisational performance and executive compensation structure data units was conducted using SPSS Statistics software (version 22).

\section{Results Characteristics of the sample}

Where the highest ranking member of the executive management was termed managing director (MD) instead of the CEO, the MD compensation information was utilised. 
Of the sampled companies, most had more than one CEO for the entire analysis period. Only $36.7 \%$ of the highest ranking executive managers retained their positions throughout the analysis period. The remaining $63.3 \%$ represent the CEO turnover among the sampled group, resulting in two or more highest ranking executive managers in charge over the analysis period. The sample was made up of 30 companies, while the period of analysis was 5 years representing five items for each measure of analysis. Thus, 150 cases were studied. The final list of companies included in the sample is shown in Box 1.

Various currencies were used by the sampled organisations for either executive compensation or annual financial reporting. The South African Rand (ZAR) was the predominant currency, with the American Dollar (USD), British Pound (GBP), Canadian Dollar (CAD) and Australian Dollar (AUD)

BOX 1: Sample of Johannesburg Stock Exchange listed mining companies used in the study.

\begin{tabular}{|ll|}
\hline African Rainbow Minerals LTD & Infrasors Holdings LTD \\
Anglo American Platinum LTD & Keaton Energy LTD \\
Anglo American PLC & Lonmin PLC \\
Aquarius Platinum LTD & Merafe Resources LTD \\
Assore LTD & Northam Platinum LTD \\
Bauba Platinum LTD & Pan African Resources PLC \\
BHP Billiton PLC LTD & Rangold \& Exploration LTD \\
Buildmax LTD & Rockwell Diamonds INC \\
Coal of Africa LTD & Sable Metals and Minerals LTD \\
Drdgold LTD & Sentula Mining LTD \\
Exxaro Resources PLC & South African Coal Mining LTD \\
Gold Fields LTD & Tawana Holdings LTD \\
Harmony Gold LTD & Trans Hex Group LTD \\
Impala Platinum LTD & Wescoal Holdings LTD \\
\hline
\end{tabular}

also represented in the sampled data. For the purpose of standardising the units of analysis, the currencies for all tested compensation components and performance measures were noted in ZAR. This was achieved by converting all the currencies to ZAR using the average exchange rates between 2009 and 2013, as the 5-year period is considered to minimise the short-term exchange rate volatility (Modau 2013).

\section{Measures of chief executive officer compensation}

The measures of CEO compensation used in the study were fixed pay and STIs. These individual measures of CEO fixed pay component of the compensation for the sampled companies (standardised to the ZAR) are illustrated in Figure 2.

It was observed that the fixed pay component of CEO compensation per organisation was generally stable over the analysis period. In contrast, the STI component of CEO compensation over the same period was volatile as shown in Figure 3. This demonstrates an expected link between the performance-dependent STIs, while the fixed pay remained constant irrespective of the organisational performance.

The descriptive statistics for each of the measures of CEO compensation utilised in the study are discussed individually in the following subsections.

\section{Fixed pay component of chief executive officer compensation}

An analysis of the fixed pay measures of executive compensation between 2009 and 2013 found that the fixed pay component of executive compensation increased at a

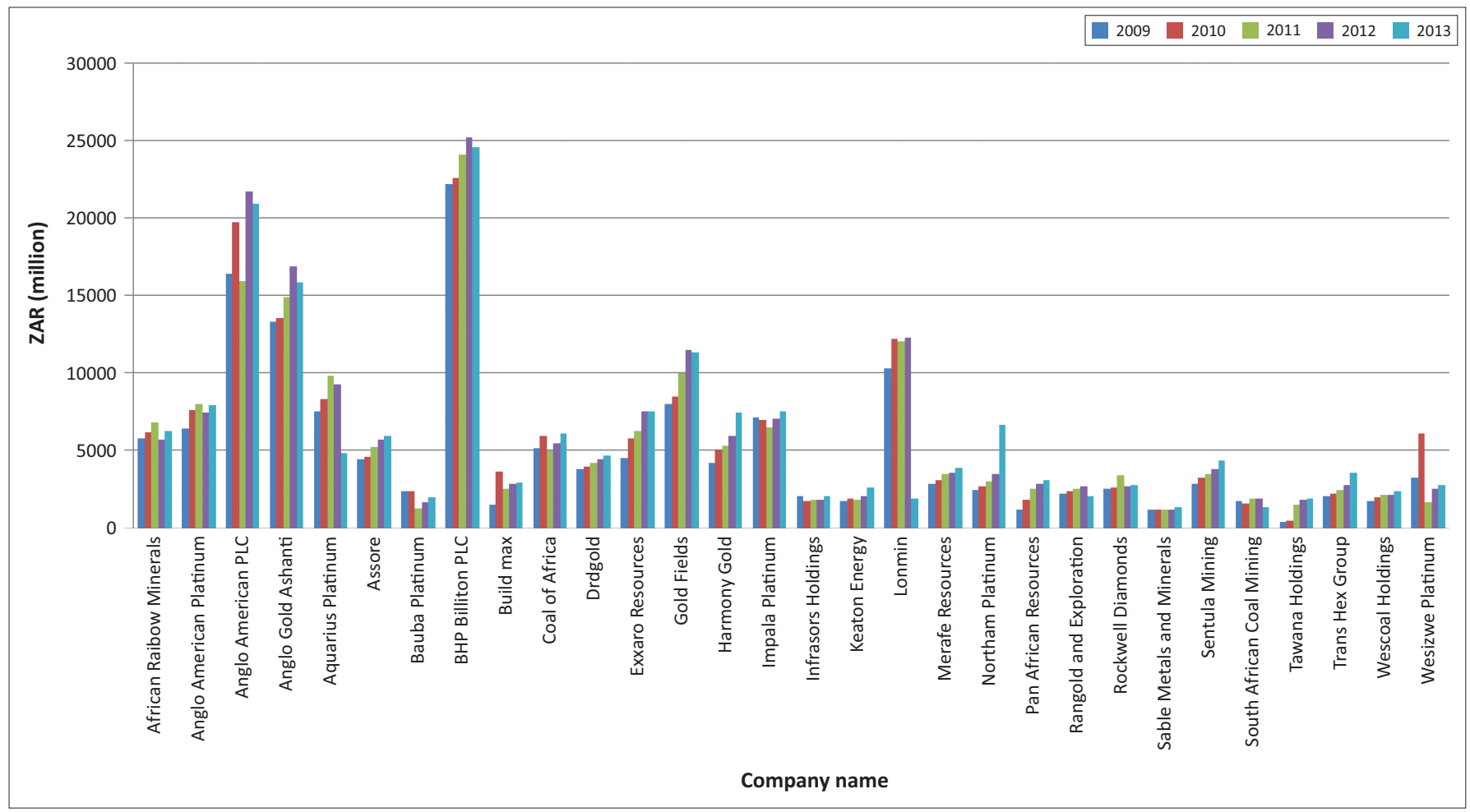

ZAR, South African Rand.

FIGURE 2: Fixed pay component of chief executive officer compensation. 


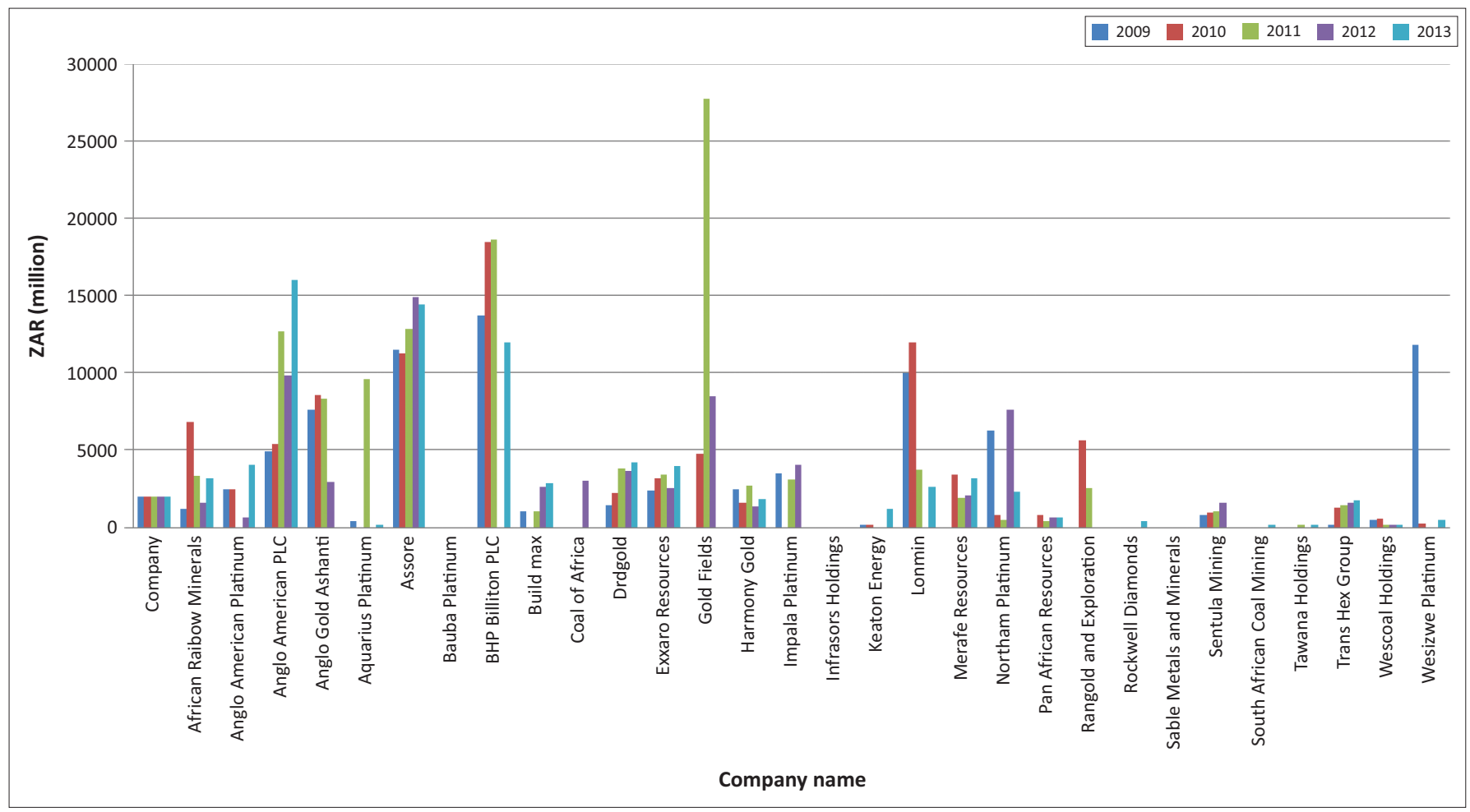

ZAR, South African Rand.

FIGURE 3: Short-term incentive pay component of chief executive officer compensation.

mean average rate of $4.4 \%$, from ZAR 5049000 to ZAR 5953000 during the period of analysis. This translates to a compound increase of $4.2 \%$ per year over the same period. The increase in the fixed component of executive pay between 2009 and 2010 was the highest within the study period at a mean average of $12.3 \%$. The increase in subsequent years was miniscule, while a negative growth was experienced in 2013 against an average inflation rate of $8.62 \%$ over the study period. The rate of increase in the mean and median remains constant throughout the period of analysis.

\section{Short-term incentive component of chief executive officer compensation}

The data show that the STI component of executive compensation remained volatile throughout the study period. An upward trend in the CEO STI compensation was recorded until a peak was reached in 2011. A downward trend was observed since the peak of 2011-2013.

\section{Measures of organisational performance}

The measures of organisational performance adopted, and the abbreviation, for the purpose of this research were as follows:

- return on equity (ROE)

- return on assets (ROA)

- asset turnover

- revenue (Rev.)

- earnings before interest, tax, depreciation and amortisation (EBITDA)

- headline earnings per share (HEPS)

- change in share price $(\Delta \mathrm{SP})$

- market capitalisation (MC).
The descriptive statistics for each measure of organisational performance are tabulated in the following subsections. The results show that both the market and accounting-based measures of performance generally reduced over the period 2009-2013.

\section{Summary of measures of organisational performance}

The descriptive statistics for measures of organisational performance show that the performance of the sampled group of mining companies was mixed for accounting-based measures, while the market-based measures generally declined over the study period. However, it appears that market-based performance was recovering by the end of the analysis period in 2013, while the majority of accountingbased performance measures were declining, with the exception of the revenue generated.

The high-level analysis suggests that the accounting measures of performance, except EBITDA, were less affected by the South African mining labour crisis of 2012 compared to the market-based measures of performance. Earnings before interest, tax, depreciation and amortisation reduced relative to revenue generated, which indicates that expenses excluding interest, tax, depreciation and amortisation increased significantly in 2012 and 2013. This resulted in HEPS remaining stable throughout the period between 2012 and 2013.

\section{Normality test}

The Shapiro-Wilk test was used to test for normality to determine whether the data were normally distributed. 
Results show that all the data were not normally distributed in all the years of study (excluding the last year) except for the change in share price in 2009, 2010, 2011 and 2012 where $p$-values of $0.309,0.157,0.108$ and 0.131 , respectively, were obtained. Since all but four of the 30 cases compared were not normally distributed, it was decided to use a non-parametric test for comparison.

\section{Test for comparison}

The Kruskal-Wallis test was used for comparison between the years on each of the variables. Since there were no missing data for the sampled group of companies, the number of observations in each year remained 30 throughout the test.

Based on the above results, there is no difference between the averages of the performance and CEO compensation measures for the tested groups over the analysis period except for the change in share price where a $p$-value of 0.033 was obtained. These results indicate that the average of the groups used in the statistical analysis remain similar, with the exception of the change in share price. As the difference between the groups was identified for the change in share price measure, it was decided to further investigate where in the data the difference was located. To test for the location of the difference, a post-hoc test (the Mann-Whitney test) was conducted. To minimise the probability of biased results, the test was made more onerous by using the Bonferroni adjustment/correction to adjust the level of significance lower. The results of the Mann-Whitney test are shown in Table 1.

Based on the above results, it is evident that all the $p$-values are greater than 0.01 ; hence, there is no statistically significant difference between the years for the change in share price measure. As the change in share price represents the change in shareholder value in the form of stock returns, the change in the average mean remains significant.
Furthermore, the higher spread around the mean together with the smaller sample size influences the results; hence, it cannot be concluded that there is no difference between the means although this is supported by statistical analysis. This is also supported by the significance that is marginally higher than the correlation coefficient threshold for pair 2, pair 3 and pair 5. While the statistical results based on the input data indicate that there is no statistically significant difference between the years for the change in share price measure, other studies using another data sample may arrive at a different conclusion.

\section{Fixed pay and organisational performance}

Pearson's product-moment correlation coefficient was used to analyse the strength of the relationship between the fixed pay component of correlated CEO compensation and measures of organisational performance. The results were mixed, with correlations observed for certain measures of organisational performance and none observed for others. Detailed results presenting the correlation coefficients are shown in Table 2.

A strong correlation was found between the fixed component of CEO compensation and the following organisational performance measures: market capitalisation, revenue and EBITDA. A weak correlation was found between the fixed component of CEO compensation and ROA. In contrast, there was no statistically significant correlation at $p<0.01$ between fixed pay and ROE, asset turnover, HEPS and the change in share price. A negative correlation coefficient was obtained between the dependent and some independent variables, namely $\mathrm{ROE}$, asset turnover and the change in share price. This suggests an inversely proportional relationship between these independent variables and the fixed pay component of CEO compensation, albeit insignificant.

TABLE 1: Mann-Whitney test results - Change in share price.

\begin{tabular}{|c|c|c|c|c|c|c|c|}
\hline Measure and tests pair & Year & $N$ & Mean & Standard deviation & Mean rank & $Z$ & Asymp. Sig. (2-tailed) \\
\hline \multirow[t]{2}{*}{ ChSharePrice Pair 1} & 2009 & 30 & 20.07 & 52.323 & 32.73 & -0.991 & 0.322 \\
\hline & 2010 & 30 & 2.27 & 33.338 & 28.27 & & \\
\hline \multirow[t]{2}{*}{ ChSharePrice Pair 2} & 2009 & 30 & 20.07 & 52.323 & 36.13 & -2.499 & 0.012 \\
\hline & 2011 & 30 & -14.33 & 28.762 & 24.87 & & \\
\hline \multirow[t]{2}{*}{ ChSharePrice Pair 3} & 2009 & 30 & 20.07 & 52.323 & 35.93 & -2.41 & 0.016 \\
\hline & 2012 & 30 & -12.38 & 35.005 & 25.07 & & \\
\hline \multirow[t]{2}{*}{ ChSharePrice Pair 4} & 2009 & 30 & 20.07 & 52.323 & 34.43 & -1.745 & 0.081 \\
\hline & 2013 & 30 & 00.60 & 66.399 & 26.57 & & \\
\hline \multirow[t]{2}{*}{ ChSharePrice Pair 5} & 2010 & 30 & 02.27 & 33.338 & 35.78 & -2.343 & 0.019 \\
\hline & 2011 & 30 & -14.33 & 28.762 & 25.22 & & \\
\hline \multirow[t]{2}{*}{ ChSharePrice Pair 6} & 2010 & 30 & 02.27 & 33.338 & 34.33 & -1.700 & 0.089 \\
\hline & 2012 & 30 & -12.38 & 35.005 & 26.67 & & \\
\hline \multirow[t]{2}{*}{ ChSharePrice Pair 7} & 2010 & 30 & 02.27 & 33.338 & 32.50 & -0.887 & 0.375 \\
\hline & 2013 & 30 & 00.60 & 66.399 & 28.50 & & \\
\hline \multirow[t]{2}{*}{ ChSharePrice Pair 8} & 2011 & 30 & -14.33 & 28.762 & 29.38 & -0.495 & 0.620 \\
\hline & 2012 & 30 & -12.38 & 35.005 & 31.62 & & \\
\hline \multirow[t]{2}{*}{ ChSharePrice Pair 9} & 2011 & 30 & -14.33 & 28.762 & 28.93 & -0.695 & 0.487 \\
\hline & 2013 & 30 & 00.60 & 66.399 & 32.07 & & \\
\hline \multirow[t]{2}{*}{ ChSharePrice Pair 10} & 2012 & 30 & -12.38 & 35.005 & 29.27 & -0.547 & 0.584 \\
\hline & 2013 & 30 & 00.60 & 66.399 & 31.73 & & \\
\hline
\end{tabular}

$N$, number; $Z$, standard score; Asymp. Sig., asymptotic significance. 
TABLE 2: Fixed pay and organisational performance correlation.

\begin{tabular}{|c|c|c|c|c|c|c|c|c|c|c|}
\hline Analysis method & Independent variables & CEO FP & ROE & ROA & AT & $\Delta \mathrm{SP}$ & MC & Rev. & EBITDA & HEPS \\
\hline \multirow[t]{8}{*}{ Sig. (1-tailed) } & CEO FP & - & 0.287 & 0.004 & 0.393 & 0.448 & 0.000 & 0.000 & 0.000 & 0.383 \\
\hline & ROE & 0.287 & - & 0.084 & 0.468 & 0.201 & 0.453 & 0.494 & 0.481 & 0.426 \\
\hline & ROA & 0.004 & 0.084 & - & 0.002 & 0.063 & 0.018 & 0.094 & 0.027 & 0.006 \\
\hline & AT & 0.393 & 0.468 & 0.002 & - & 0.002 & 0.380 & 0.391 & 0.475 & 0.058 \\
\hline & $\triangle \mathrm{SP}$ & 0.448 & 0.201 & 0.063 & 0.002 & - & 0.131 & 0.254 & 0.224 & 0.056 \\
\hline & $\mathrm{MC}$ & 0.000 & 0.453 & 0.018 & 0.380 & 0.131 & - & 0.000 & 0.000 & 0.395 \\
\hline & EBITDA & 0.000 & 0.481 & 0.027 & 0.475 & 0.224 & 0.000 & 0.000 & - & 0.049 \\
\hline & HEPS & 0.383 & 0.426 & 0.006 & 0.058 & 0.056 & 0.395 & 0.423 & 0.049 & - \\
\hline \multirow{8}{*}{$\begin{array}{l}\text { Pearson's } \\
\text { correlation }\end{array}$} & CEO FP & 1 & -0.046 & 0.219 & -0.022 & -0.011 & 0.866 & 0.784 & 0.750 & 0.025 \\
\hline & ROE & -0.046 & 1 & 0.113 & 0.007 & 0.069 & -0.010 & -0.001 & 0.004 & 0.015 \\
\hline & ROA & 0.219 & 0.113 & 1 & 0.232 & 0.126 & 0.172 & 0.108 & 0.157 & 0.204 \\
\hline & AT & -0.022 & 0.007 & 0.232 & 1 & 0.228 & -0.025 & -0.023 & 0.005 & 0.129 \\
\hline & $\Delta \mathrm{SP}$ & -0.011 & 0.069 & 0.126 & 0.228 & 1 & 0.092 & 0.055 & 0.063 & 0.131 \\
\hline & Rev. & 0.784 & -0.001 & 0.108 & -0.023 & 0.055 & 0.928 & 1 & 0.939 & 0.016 \\
\hline & EBITDA & 0.750 & 0.004 & 0.157 & 0.005 & 0.063 & 0.879 & 0.939 & 1 & 0.135 \\
\hline & HEPS & 0.025 & 0.015 & 0.204 & 0.129 & 0.131 & 0.022 & 0.016 & 0.135 & 1 \\
\hline
\end{tabular}

Note: The numbers in bold indicate the independent variables correlating with the fixed compensation component of CEO compensation, that is, ROA, market capitalisation, revenue and EBITDA. CEO FP, chief executive officer fixed pay; ROE, return on equity; ROA, return on assets; AT, asset turnover; $\triangle \mathrm{SP}$, change in share price; MC, market capitilisation; Rev., revenue; EBITDA, earnings before interest tax depreciation and amortisation; HEPS, headline earnings per share; Sig., significance.

\section{Short-term incentive and organisational performance}

Pearson's product-moment correlation coefficient was used to analyse the strength of the relationship between the short-term incentive components of CEO compensation and measures of organisational performance. Table 3 shows that the independent variables significantly correlating with the STI component of CEO compensation are ROA, market capitalisation, revenue and EBITDA.

A strong correlation was found between the STI component of CEO compensation and two measures of organisational performance, namely market capitalisation and EBITDA. The STI component of CEO compensation is moderate, correlating with revenue return and EBITDA. Furthermore, a weak correlation was found between the STI component of CEO compensation and the change in share price and ROA. Lastly, there was no statistically significant correlation between the STI component of CEO compensation and the last two measures of performance, namely ROE and asset turnover. The correlation coefficient between the dependent and the independent variable was universally positive, which depicts a positive relationship (Pallant 2013).

\section{Multivariate regression analysis: Fixed pay}

The multicollinearity test was conducted on performance measures that were correlated with the fixed pay component of CEO compensation. Based on multicollinearity test results, revenue was removed from further analysis because its collinearity statistics exceeded the limit of 10 for variance inflation factor (VIF) and had the lowest tolerance (Pallant 2013). In addition, the outliers were identified using histogram of data residuals, and they were also excluded from the analysis.

A Durbin-Watson score of 0.648 was obtained from the results, which indicates that the data were positively autocorrelated. However, this was aligned with expectations because the data for each of the sampled organisations over the period of 5 years were expected to bear some resemblance.

The coefficient of determination ( $R$ squared) is the measure of the model prediction accuracy. The $R$ squared for the current study was 0.693 , which suggests that $69.3 \%$ of the variations in fixed pay were explained by the independent variables (the fixed pay component of CEO compensation) in the model. Further, the iterative analysis process of the CochraneOrcutt method reduced the Durbin-Watson to 2.049 against the target level of 2, which suggests that the autocorrelation problem was significantly minimised after five iterations. The results of the analysis of variance (ANOVA) associated with the model are shown in Table 4.

The regression coefficients for the model are shown in Table 5. It was found that market capitalisation and the constant are the most dominant predictors of the fixed pay component of CEO compensation. The constant refers to the minimum fixed pay for the least paid CEO within the industry over the analysis period.

\section{Multivariate regression analysis: Short-term incentive}

The same assumptions and process used for fixed compensation was also used for STIs. A multicollinearity test was conducted on performance measures that were correlated with the short-term component of CEO compensation. Similarly, revenue was excluded from further analysis based on the results of the test as the collinearity statistics exceeded the limit of 10 for VIF and had the lowest tolerance (Pallant 2013). The outliers were subsequently exempted from further analysis.

A Durbin-Watson score of 1.516 was obtained from the results, which indicates that the data were positively auto-correlated. However, the level of autocorrelation was lower than in the case of fixed pay, as it was closer to the target score of 2 . 
TABLE 3: Short-term incentive and organisational performance correlation.

\begin{tabular}{|c|c|c|c|c|c|c|c|c|c|c|}
\hline Analysis method & Independent variables & CEO STI & ROE & ROA & AT & $\Delta \mathrm{SP}$ & MC & Rev. & EBITDA & HEPS \\
\hline \multirow[t]{9}{*}{ Sig. (1-tailed) } & CEO_STI & - & 0.409 & 0.000 & 0.162 & 0.050 & 0.000 & 0.000 & 0.000 & 0.000 \\
\hline & ROE & 0.409 & - & 0.084 & 0.468 & 0.201 & 0.453 & 0.494 & 0.481 & 0.426 \\
\hline & ROA & 0.000 & 0.084 & - & 0.002 & 0.063 & 0.018 & 0.094 & 0.027 & 0.006 \\
\hline & AT & 0.162 & 0.468 & 0.002 & - & 0.002 & 0.380 & 0.391 & 0.475 & 0.058 \\
\hline & $\Delta \mathrm{SP}$ & 0.050 & 0.201 & 0.063 & 0.002 & - & 0.131 & 0.254 & 0.224 & 0.056 \\
\hline & MC & 0.000 & 0.453 & 0.018 & 0.380 & 0.131 & - & 0.000 & 0.000 & 0.395 \\
\hline & Rev. & 0.000 & 0.494 & 0.094 & 0.391 & 0.254 & 0.000 & - & 0.000 & 0.423 \\
\hline & EBITDA & 0.000 & 0.481 & 0.027 & 0.475 & 0.224 & 0.000 & 0.000 & - & 0.049 \\
\hline & HEPS & 0.000 & 0.426 & 0.006 & 0.058 & 0.056 & 0.395 & 0.423 & 0.049 & - \\
\hline \multirow{8}{*}{$\begin{array}{l}\text { Pearson's } \\
\text { correlation }\end{array}$} & CEO_STI & 1 & 0.019 & 0.294 & 0.081 & 0.135 & 0.518 & 0.468 & 0.506 & 0.339 \\
\hline & ROE & 0.019 & 1 & 0.113 & 0.007 & 0.069 & -0.010 & -0.001 & 0.004 & 0.015 \\
\hline & ROA & 0.294 & 0.113 & 1 & 0.232 & 0.126 & 0.172 & 0.108 & 0.157 & 0.204 \\
\hline & AT & 0.081 & 0.007 & 0.232 & 1 & 0.228 & -0.025 & -0.023 & 0.005 & 0.129 \\
\hline & $\Delta \mathrm{SP}$ & 0.135 & 0.069 & 0.126 & 0.228 & 1 & 0.092 & 0.055 & 0.063 & 0.131 \\
\hline & $\mathrm{MC}$ & 0.518 & -0.010 & 0.172 & -0.025 & 0.092 & 1 & 0.928 & 0.879 & 0.022 \\
\hline & EBITDA & 0.506 & 0.004 & 0.157 & 0.005 & 0.063 & 0.879 & 0.939 & 1 & 0.135 \\
\hline & HEPS & 0.339 & 0.015 & 0.204 & 0.129 & 0.131 & 0.022 & 0.016 & 0.135 & 1 \\
\hline
\end{tabular}

CEO STI, chief executive officer short-term incentive; ROE, return on equity; ROA, return on assets; AT, asset turnover; $\triangle$ SP, change in share price; MC, market capitilisation; Rev., revenue; EBITDA, earnings before interest tax depreciation and amortisation; HEPS, headline earnings per share; Sig., significance.

TABLE 4: Analysis of variance - Fixed pay.

\begin{tabular}{lccc}
\hline ANOVA & Sum of squares & $d f$ & Mean square \\
\hline Regression & 1011999048.926 & 3 & 337333016.309 \\
Residual & 448651037.984 & 141 & 3181922.255 \\
\hline
\end{tabular}

ANOVA, analysis of variance; $d f$, degrees of freedom.

TABLE 5: Regression coefficients - Fixed pay.

\begin{tabular}{|c|c|c|c|c|c|}
\hline \multirow[t]{2}{*}{ Variables } & \multicolumn{2}{|c|}{ Unstandardised coefficients } & \multirow{2}{*}{$\begin{array}{l}\text { Standardised } \\
\text { coefficients }(\beta)\end{array}$} & \multirow[t]{2}{*}{$t$} & \multirow[t]{2}{*}{ Sig. } \\
\hline & B & SE & & & \\
\hline ROA & 0.685 & 2.799 & 0.012 & 0.245 & 0.807 \\
\hline MC & 3.067E-08 & 0.000 & 0.758 & 7.997 & 0.000 \\
\hline EBITDA & $1.081 \mathrm{E}-05$ & 0.000 & 0.082 & 0.859 & 0.392 \\
\hline (Constant) & 3708.487 & 511.106 & - & 7.256 & 0.000 \\
\hline
\end{tabular}

$B$, regression; SE, standard error; $\beta$, beta; ROA, return on assets; $M C$, market capitilisation EBITDA, earnings before interest tax depreciation and amortisation; Sig., significance; $t$, t-statistic.

The $R$ squared for the study was 0.486 , significantly lower than the $R$ squared recorded for fixed pay studies detailed above. The final Durbin-Watson in the model was 1.969, which was closer to the target value of 2 . Analysis of variance studies are also shown in Table 6, followed by the regression coefficient results in Table 7.

Using a similar regression coefficient results interpretation process, it was found that HEPS was the most dominant predictor of the STI component of CEO compensation. The constant in the model indicates that, statistically, CEOs for the sampled group of organisations received STIs within the analysis period.

\section{Discussion}

The main objective of this research was to examine the relationship between measures of CEO compensation and organisational performance in the South African mining industry. Results show that CEO compensation was positively linked with organisational performance (an increase in CEO compensation was linked to an increase in organisational performance), as each of the individual CEO compensation measures showed a moderate to strong positive relationship with the majority of performance measures considered.
TABLE 6: Analysis of variance - Short-term incentive.

\begin{tabular}{lccc}
\hline Analysis & Sum of squares & $d f$ & Mean square \\
\hline Regression & 861667889.547 & 4 & 215416972.387 \\
Residual & 910264488.598 & 139 & 6548665.386
\end{tabular}

$d f$, degrees of freedom.

TABLE 7: Regression coefficients - Short-term incentive.

\begin{tabular}{|c|c|c|c|c|c|}
\hline \multirow[t]{2}{*}{ Variables } & \multicolumn{2}{|c|}{ Unstandardised coefficients } & \multirow{2}{*}{$\begin{array}{l}\text { Standardised } \\
\text { coefficients ( } \beta \text { ) }\end{array}$} & \multirow[t]{2}{*}{$t$} & \multirow[t]{2}{*}{ Sig. } \\
\hline & B & SE & & & \\
\hline ROA & 8.911 & 4.325 & 0.129 & 2.060 & 0.041 \\
\hline MC & $1.281 \mathrm{E}-08$ & 0.000 & 0.346 & 2.467 & 0.015 \\
\hline EBITDA & $2.456 \mathrm{E}-05$ & 0.000 & 0.182 & 1.282 & 0.202 \\
\hline HEPS & 0.265 & 0.048 & 0.354 & 5.498 & 0.000 \\
\hline (Constant) & 1509.322 & 317.527 & - & 4.753 & 0.000 \\
\hline
\end{tabular}

$B$, regression; $\mathrm{SE}$, standard error; $\beta$, beta; ROA, return on assets; $\mathrm{MC}$, market capitilisation; EBITDA, earnings before interest tax depreciation and amortisation; HEPS, headline earnings per share; Sig., significance; $t$, t-statistic.

The measures of organisational performance that display a positive relationship with the fixed component of CEO compensation are ROA, market capitalisation, revenue and EBITDA. (In other words, an increase in the fixed component of CEO compensation was linked to an increase in ROA, market capitalisation, revenue and EBITDA.) The universal characteristics of these measures of compensation are that they are all linked with either revenue or the organisation size, which then share a positive relationship. As high revenue is mainly a sub-product of large companies, the results appear to indicate that the fixed pay component was mainly dependant on the organisation size.

These results are in line with earlier findings by Barber, Ghiselli and Deale (2006) which suggested that there was a positive relationship between $\mathrm{CEO}$ compensation and revenue. The strong relationship found between the fixed pay component of CEO compensation and market capitalisation supports a prior study by Modau (2013) which suggested a direct relationship between fixed compensation and market capitalisation.

The results differ from the findings of studies by Bussin and Blair (2015) and Van Blerck (2012) which found a statistically 
significant correlation between share price and CEO compensation. However, the difference between the studies is that van Blerck used the total remuneration, whereas Bussin and Blair also included the long-term component of CEO compensation. Another area of difference in results concerns ROE. Although this study did not find a significant relationship between $\mathrm{ROE}$ and the fixed pay component of CEO compensation, Shaw (2011) found a weak relationship between ROE and the three measures of CEO performance he considered, namely fixed pay, STIs and total remuneration. In addition, De Wet (2012) found a positive relationship between CEO compensation and ROE in all industries, although his study used the total CEO remuneration, instead of fixed pay as the dependant variable.

STI compensation was found to be strongly correlated with market capitalisation and EBITDA. A moderate relationship was observed for STI CEO compensation with revenue and HEPS, and a weak relationship was observed between the STI component of CEO compensation with ROA and share price. No significantly negative relationship was observed between the two compensation measures and any of the organisational performance measures considered in the research. It can therefore be inferred that there is no basis to claim an inverse proportional relationship between organisational performance and CEO compensation.

The biggest contributor to the fixed pay component of CEO compensation was market capitalisation, whereas earnings per share was the biggest contributor to the short-term compensation. The study results also indicate that organisation size plays a key role in determining CEO compensation as it was the predominant determinant of fixed pay and the third highest determinant of STI compensation. This finding supports Tervio (2008) who observed a strong link between executive compensation and organisation size, but differs from Bizjak, Lemmon and Nguyen (2011) who argued that the organisational characteristics are the most dominant factor compared with organisation size. Proponents for the alignment between pay and responsibility may argue that the characteristics depict an optimal design for CEO compensation the larger the organisation, the greater the level of CEO compensation. However, detractors may argue that the level of responsibility associated with sustainably running and growing a smaller organisation is greater considering resource constraints and disruption by competitors, especially in a price-taking industry where volumes produced represent competitive edge. The key is for compensation committees to find the balance to ensure optimal compensation based on the individual characteristics of each organisation.

It appears that the operating expenses excluding interest, tax, depreciation and amortisation across the industry increased in 2012 and 2013. Although the main driving force behind the increase was not investigated, the adjustment of employees' wages following industrial action was believed to have played a role. Based on the analysis of fixed pay information for the sampled mining companies over the study period, it appears that the rate of change in fixed pay has not been as high as reported in the media. However, the miniscule increase observed was off a higher base relative to general workers in South Africa.

\section{Limitations}

This study was limited to JSE listed companies because of the availability of audited financial reports in line with the King III report on corporate governance; hence, the findings may not be valid for non-listed companies as they may not be subscribing to the King III corporate governance principles. The study excluded the long-term stock options data because of the research time constraints and related data accessibility challenges. As this information was described by Ozkan (2011) as potentially the most performance sensitive component of compensation, the validity of study results may be limited where the compensation structure differs from the sampled data. A further limitation is the exclusion of LTIs.

\section{Practical implications and recommendations}

Sentiments in the reviewed media articles, which criticised executive compensation levels with respect to the alignment with organisational performance, appear to be somewhat unfounded. The results indicate that there is no relationship between the change in share price and the fixed pay component of CEO compensation, whereas a weak relationship was observed with respect to the short-term compensation. As performance may be affected by other external factors including a period of good performance throughout the market and sector (Gregg et al. 2012), it seems prudent to assume that the fixed pay compensation may not be linked to share performance. On the contrary, the alignment of the share performance with CEO performance was mainly achieved through long-term share options, which did not form part of the research. The appearance of the weak, but positive relationship between share performance and the STI component of CEO compensation indicates that share performance played a minor role compared with other measures of performance in the STI compensation characteristic.

More recent research by Deloitte (2017) looked at the relationship between executive compensation and organisational performance over the years 2010-2016. In this study, the Mining, Construction and Resource (MRC) sector was found to have destroyed value, to the extent of approximately a third: whereas other sectors had grown organisational value approximately twofold, the MRC sector had more than halved organisational value. During this period, the impact on MRC executive compensation was not significantly affected, and shareholder and organisational misfortune was not correlated with executive compensation.

The Deloitte study was not limited to the mining sector (the construction and resource sectors were included in their sector categorisation) and also covered a different time period to this research study. The results, however, warrant attention in light of recent events where measures of organisational 
performance have been deliberately obfuscated. The recent corporate scandals involving multinational organisations such as Steinhoff and KPMG show how important it is to get clarity on the real earnings in an organisation, which has both income statement and balance sheet implications. Ted Black (2018) asserts that most boards are ineffective as they review results retrospectively and are always the last to know how well or badly an organisation is doing. He states that:

rewarding CEOs with share options does not make CEOs think like 'owners' - the original aim. Instead they think like investment bankers and analysts. If the goal is to maximise shareholder value rather than the value-of-the-firm (VOF) - based on productivity, not the share price - then you will get unethical, even fraudulent, behaviour. (Black 2018:2)

The ability to defraud and misrepresent accounting measures of organisational performance places a significant responsibility on boards and executives to interrogate the voracity of organisational performance and align this fairly with executive compensation. The results of this study indicate that the organisation size is potentially the key focal point, as it plays an important role in the level of compensation and STIs. Thus, the boards of large companies need to prevent rent seeking behaviour by managing the overall performance measurement contribution of processes that are significantly influenced by the organisation size. Likewise the boards of smaller companies also need to design innovative compensation contracts that incorporate the effects of the strong relationship between the organisation size and total remuneration, and simultaneously mitigate non-value adding upward biased compensation.

Corporate governance has not prevented these scandals and acts of fraud from occurring, and in light of this, increasingly stringent regulation is likely. Greater scrutiny and involvement in the disclosure, quantum and the delivery mechanisms of executive pay by institutional investors can also be expected (Deloitte 2017). In South Africa, King IV will enable increased levels of dialogue between companies and their shareholders and this in turn should have a positive impact on the structure of remuneration policies and the quality of disclosure in implementation policies. King IV will also provide a platform for enhanced shareholder vigilance and activism.

Although CEO compensation and organisational performance appear to be positively related, the results may not hold for all organisations included in the sector. It is therefore recommended that organisations' boards consider regularly reviewing the $\mathrm{CEO}$ compensation structure with an objective to maximise performance within a particular contracting period taking the prevailing and forecasted environmental factors into consideration. Pay for performance sensitivity should be implemented to reward good and punish bad performance. Moreover, developing a robust model that uses real-time data from databases like McGregor to design CEO compensation and also forecasts the likely outcome based on the strategies implemented relative to competition should be considered.

\section{Conclusion}

Executive compensation is a key mechanism to ensure that agents are optimally incentivised to maximise the principal's value. It is an important tool that can assist the business to grow if efficiently designed, and potentially destroy shareholder wealth if inefficiently designed. To balance the need for long-term business sustainability, sustainable growth and optimal CEO compensation levels, a holistic design approach that serves as the driving force behind organisational goals is vital. The use of valid accounting measures and associated checks and balances are key to accurately assessing organisational performance. If executive compensation is to be linked to organisational performance, the measurement of this performance must be validated and overseen by the board.

The historically low wages widely associated with low productivity levels are regarded as the source of the challenging labour relations environment that is prevailing in the mining sector in South Africa. To improve the situation, an open and authentic dialogue by all involved stakeholders will be required in the interest of the long-term sustainability of the sector. King IV will hopefully play a significant role in enabling this dialogue. Policy, together with mutual respect between management and labour movements, will serve as a key feature to underpin the road to recovery for the mining sector.

\section{Acknowledgments Competing interests}

The author declares that he has no financial or personal relationships that may have inappropriately influenced him in writing this article.

\section{References}

Antin, D., 2013, 'The South African mining sector: An industry at a crossroads', Hanns Seidel-Foundation, viewed 04 March 2014, from http://www.hss.de/fileadmin/ suedafrika/downloads/

Barber, N., Ghiselli, R. \& Deale, C., 2006, 'Assessing the relationship of CEO compensation and company financial performance in the restaurant segment of the hospitality industry', Journal of Foodservice Business Research 9(4), 65-82. https://doi.org/10.1300/J369v09n04_05

Bebchuk, L.A. \& Fried, J.M., 2004, Pay without performance: The unfulfilled promise of executive compensation, Harvard University Press, Cambridge, MA.

Bebchuk, L.A., Fried, J.M. \& Walker, D.I., 2002, 'Managerial power and rent extraction in the design of executive compensation', University of Chicago Law Review 69, 751-846. https://doi.org/10.2307/1600632

Bizjak, J., Lemmon, M. \& Nguyen, T., 2011, 'Are all CEOs above average? An empirical analysis of compensation peer groups and pay design', Journal of Financial Economics 100(3), 538-555. https://doi.org/10.1016/j.jfineco.2011.02.007

Black, T., 2018, 'Steinhoff: These 6 charts should have alerted the board', Biznews, viewed 28 April 2018, from https://www.biznews.com/global-investing/2018/ 02/26/6-steinhoff-charts-alerted-board/

Bussin, M., 2012, The Remuneration Handbook for Africa: A practical and informative handbook for managing and recognition in Africa, Knowres Publishing, Randburg.

Bussin, M., 2015, 'CEO pay performance sensitivity in the South African context', South African Journal of Economic and Management Sciences 18(2), 1-13. https:// South African Journal of Economic and
doi.org/10.4102/sajems.v18i2.838

Bussin, M. \& Blair, C., 2015, 'Financial indicators of company performance in different industries that affect CEO remuneration in South Africa', South African Journal of Economic and Management Sciences 18(4), 1-13. https://doi.org/10.4102/ sajems.v18i4.1249

Bussin, M. \& Nel, M., 2015, 'Relationship between CEO remuneration and company financial performance in the South African retail and consumer goods sector', Acta Commercii 15(1), Art. \#240, 11 pages. https://doi.org/10.4102/ac.v15i1.240

Cairns, P., 2017, 'Steinhoff: 'We didn't believe the numbers', Moneyweb, viewed 28 April 2018, from https://www.moneyweb.co.za/news/companies-and-deals/ steinhoff-we-didnt-believe-the-numbers/ 
Cao, M. \& Wang, R., 2013, 'Optimal CEO compensation with search: Theory and empirical evidence', The Journal of Finance 68(5), 2001-2058. https://doi.org/ 10.1111/jofi.12069'

Deloitte, 2017, Shareholder alignment, company performance and executive pay, Deloitte Executive Compensation Report, viewed 28 April 2018, from https:// www2.deloitte.com/za/en/pages/human-capital/articles/executive-compensationreport.html

Carte, D., 2011, 'Executive remuneration survey: Miners strike gold in SA pay stakes Corporate governance', Moneyweb, viewed 22 April 2014, from http://www. moneyweb.co.za/moneyweb-corporate-governance/executive-remunerationsurvey-miners-strike-gold-i

Crowley, K., 2013, Mining CEO pay attacked by South African fund managers, viewed 22 April 2014, from http://www.bloomberg.com/news/2013-10-29/mining-ceopay-attacked-by-south-african-fund-managers.htm

De Wet, J.H.V., 2012, 'Executive compensation and the EVA and MVA performance of South African listed companies', Southern African Business Review 16(3), $57-80$

Edmans, A. \& Gabaix, X., 2009, 'Is CEO pay really inefficient? A survey of new optimal contracting theories', European Financial Management 15(3), 486-496. https:// doi.org/10.1111/j.1468-036X.2009.00500.x

Eisenhardt, K.M., 1989, 'Agency theory: An assessment and review', Academy of Management Review 14(1), 57-74. https://doi.org/10.5465/amr.1989. 4279003

Ernst \& Young, 2013, Remuneration governance in South Africa: 2013 survey results, remuneration committees under pressure, viewed 21 April 2014, from http:// www.ey.com/Publication/vwLUAssets/Remuneration_Governance_in_South_ Africa/\$FILE/EY\%202103\%20Survey\%20Remuneration\%20Governance.p pd

Faulkender, M., Kadyrzhanova, D., Prabhala, N. \& Senbet, L., 2010, 'Executive compensation: An overview of research on corporate practices and proposed reforms', Journal of Applied Corporate Finance 22(1), 107-118. https://doi org/10.1111/j.1745-6622.2010.00266.x

Frydman, C. \& Saks, R.E., 2010, 'Executive compensation: A new view from a longterm perspective 1936-2005', Review of Financial Studies 23(5), 2099-2138. https://doi.org/10.1093/rfs/hhp120

Goergen, M. \& Renneboog, L., 2011, 'Managerial compensation', Journal of Corporate Finance 17(4), 1068-1077. https://doi.org/10.1016/j.jcorpfin.2011.06.002

Graffin, S.D., Boivie, S. \& Carpenter, M.A., 2013, 'Examining CEO succession and the role of heuristics in early-stage CEO evaluation', Strategic Management Journa 34(4), 383-403. https://doi.org/10.1002/smj.2019

Gregg, P., Jewell, S. \& Tonks, I., 2012, 'Executive pay and performance: Did bankers' bonuses cause the crisis?', International Review of Finance 12(1), 89-122. https:// doi.org/10.1111/j.1468-2443.2011.01136.x

Higgins, R.C., 2009, Analysis for financial management, McGraw Hill, Singapore.

IoDSA, 2009, King report on corporate governance in SA - Institute of Directors in Southern Africa (IoDSA), viewed 03 November 2014, from http://www.iodsa. co.za/?page=kingIII

Jensen, M.C., 1983, 'Organization theory and methodology', Accounting Review 58(2), 319-339.

Jensen, M.C. \& Meckling, W.H., 1976, 'Theory of the firm: Managerial behavior, agency costs and ownership structure', Journal of Financial Economics 3(4), 305-360. https://doi.org/10.1016/0304-405X(76)90026-X

Jensen, M.C. Murphy, K.J., 1990, 'Performance pay and top-management incentives', Journal of Political Economy 98(2), 225-264. https://doi.org/10.1086/261677
Jensen, M.C. \& Murphy, K.J., 2010, 'CEO incentives-It's not how much you pay, but how*', Journal of Applied Corporate Finance 22(1), 64-76. https://doi.org/10.1111/ j.1745-6622.2010.00262.x

Lee, G.J., 2016, 'Transcending paradox in the realm of South African executive pay', in 'Critical Management Studies in the South African context', Acta Commercii, suppl. 1, 16(2), a418. https://doi.org/10.4102/ac.v16i2.418

Modau, M.F., 2013, 'The relationship between Chief Executive Officer (CEO) remuneration and financial performance of an organisation', Unpublished master's thesis, University of Pretoria, Pretoria.

Molele, C. \& Letsoalo, M., 2012, Pay disparity blamed for mine unrest, viewed 22 April 2014, from http://mg.co.za/article/2012-09-14-00-pay-disparity-blamed-for-unrest/

Murphy, K.J., 1985, 'Corporate performance and managerial remuneration - An empirical analysis', Journal of Accounting \& Economics 7(1/2/3), 11-42. https:// doi.org/10.1016/0165-4101(85)90026-6

Nyberg, A.J., Fulmer, I.S., Gerhart, B. \& Carpenter, M.A., 2010, 'Agency theory revisited: CEO return and shareholder interest alignment', Academy of Management Journal 53(5), 1029-1049. https://doi.org/10.5465/amj.2010.54533188

O'Reilly, C.A. \& Main, B.G., 2010, 'Economic and psychological perspectives on CEO compensation: A review and synthesis', Industrial and Corporate Change 19(3), 675-712. https://doi.org/10.1093/icc/dtp050

Ozkan, N., 2011, 'CEO compensation and firm performance: An empirical investigation of UK panel data: CEO compensation and firm performance', European Financial Management 17(2), 260-285. https://doi.org/10.1111/j.1468-036X.2009.00511.x

Pallant, J., 2013, SPSS survival manual: A step by step guide to data analysis using IBM SPSS, 5th edn., McGraw Hill, Maidenhead.

Rau, R., 2017, 'Executive compensation', Foundations and Trends in Finance 10(3-4), $181-362$.

Schneider, P.J., 2013, 'The managerial power theory of executive compensation', Journal of Financial Service Professionals 67(3), 16-31.

Seccombe, A., 2013, Mining executives' pay packets questioned by funds, viewed 22 April 2014, from http://www.bdlive.co.za/business/mining/2013/10/31/ mining-executives-pay-packets-questioned-by-funds

Shaw, K.W. \& Zhang, M.H., 2010, 'Is CEO cash compensation punished for poor firm performance?', The Accounting Review 85(3), 1065-1093. https://doi.org/10.2308/ accr.2010.85.3.1065

Shaw, P.A., 2011, CEO pay-performance sensitivity in South African financial services companies, MBA dissertation, University of Pretoria, Pretoria.

Steyn, L., 2013, 'Mine bosses rake in the big bucks', viewed 22 April 2014, from http:// mg.co.za/article/2013-07-26-00-mine-bosses-rake-in-the-big-bucks/

Tervio, M., 2008, 'The difference that CEOs make: An assignment model approach', American Economic Review 98(3), 642-668. https://doi.org/10.1257/aer.98.3.642

Topazio, N., 2008, 'Executive remuneration', Financial Management 3, 40-42.

Tosi Jr, H.L. \& Gomez-Mejia, L.R., 1989, 'The decoupling of CEO pay and performance: An agency theory perspective', Administrative Science Quarterly 34(2), 169-189. https://doi.org/10.2307/2989894

Van Blerck, T.G., 2012, 'The relationship between executive remuneration at financial institutions and economic value added', MBA dissertation, University of Pretoria, Pretoria.

Van der Berg, S., 2014, 'Inequality, poverty and prospects for redistribution', Development Southern Africa 31(2), 197-218. https://doi.org/10.1080/037683 5X.2013.871196

Van Vuuren, A.J., 2013, Mining CEOs rake in the cash, viewed 22 April 2014, from http://www.citypress.co.za/business/mining-ceos-rake-in-the-cash/ 